\title{
Review
}

\section{From plant physiology to human metabolic investigations*}

\author{
P.J. Lefèbvre \\ Division of Diabetes, Institute of Medicine, University of Liège, Liège, Belgium
}

Claude Bernard, who died 106 years ago, is celebrated as the greatest physiologist of his century. Others, in this memorial Lecture, have recalled some of his major achievements. As stated by Robin, "if one were to select the single characteristic that makes Claude Bernard a giant compared to most other experimentalists, it would be his ability to deduce general principles from scientific facts" [1]. In the nineteenth century, the very art of conceptualizing was a revolutionary approach and Bernard considered conceptualization to be an integral part of the scientific process. Among the general concepts developed by Claude Bernard are: (1) the application of the experimental method to medicine and physiology; (2) the unity of medicine and physiology; and (3) the relationship between the clinic and the research laboratory in medical science [1].

The ideas of Claude Bernard have been well received in Belgium, particularly in my home University of Liège where my mentors have always encouraged clinicians to be involved in research, which is precisely what I have attempted to do. Twenty-five years of research cannot be summarized in a 45-min lecture. I have chosen to make four points: (1) that simple, even elementary, biological observations can lead to clinical applications; (2) that, in contrast, animal investigations can promptly bring answers to questions raised in clinical practice; (3) that an interdisciplinary approach to problems is often most fruitful; and, (4) that whatever the circumstances, clinical practice can not be dissociated from research.

The first three points will be illustrated by examples originating from our own laboratory, the fourth comes from history.

\section{Elementary biological observations can lead to clinical application}

In the late fifties to early sixties, various investigators started to screen systematically the antiinflammatory properties of every known hormone. Such interest re-

* 1984 Claude Bernard Lecture of the European Association for the Study of Diabetes delivered in London on 15 September 1984 sulted from the unprecedented success of the use of adrenal steroids and their derivatives as antiinflammatory agents. Preliminary observations had suggested that glucagon might have beneficial effects on rheumatoid arthritis [2]. So, we started to investigate whether glucagon had indeed anti-inflammatory properties. Our experimental protocol was most simple: it consisted of seeing whether glucagon given intraperitoneally to rats would prevent the oedema resulting from an injection in the paw of inflammatory agents, such as histamine, dextran or formaline. Series of animals received saline, others received glucagon and the magnitude of the oedema was evaluated by plethysmography or even more simply by measurement of the circumference of the paw. This is the type of elementary protocol that can be offered to a student for his (or her) first contact with experimental animal research. We soon demonstrated that indeed glucagon markedly inhibited the local oedema due to the injection of these phlogistic drugs [3, 4], but that this effect was totally abolished by previous adrenalectomy [5]. Our first interpretation was that glucagon stimulated the release of adrenal corticosteroids

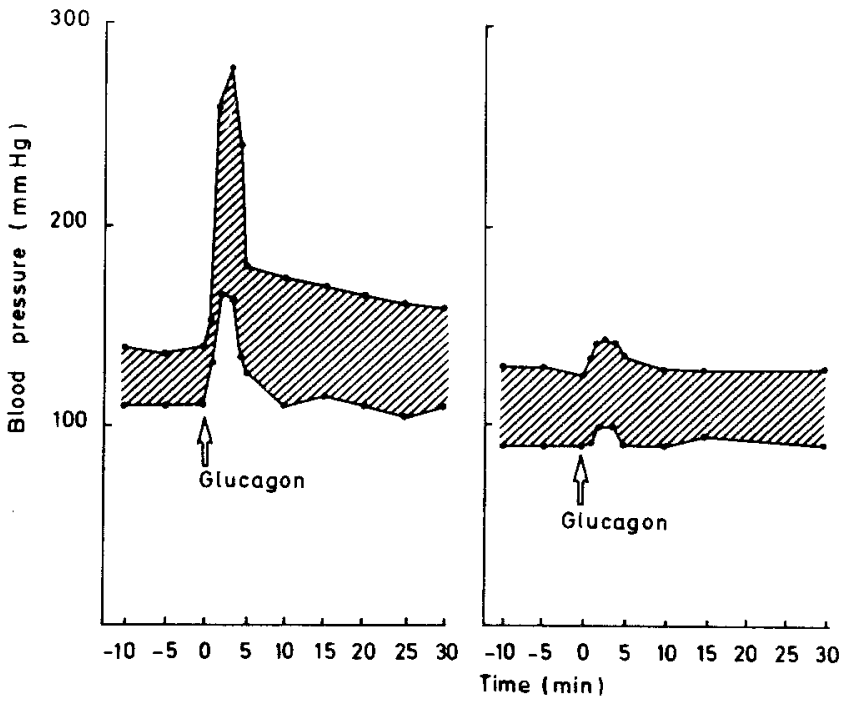

Fig. 1. Changes in blood pressure after intravenous administration of $1 \mathrm{mg}$ glucagon in a patient with pheochromocytoma (left panel); lack of significant changes 6 weeks after removal of the tumour (right panel). [From Lefèbvre et al. - 11] 
and that these were responsible for the anti-inflammatory effect. To our surprise, glucagon, under our experimental conditions, did not modify corticosteroid-circulating levels [6]. The second thought was that glucagon might release adrenal catecholamines and that these, by peripheral vasoconstriction, could prevent formation of oedema. This idea was soon proven to be the case, since glucagon unequivocally stimulated the release of catecholamines from the isolated perfused rat adrenals [7], while the antiphlogistic action of glucagon was abolished by an adrenolytic drúg and reproduced by an intraperitoneal injection of adrenaline [8]. Needless to say, glucagon has never been used as an anti-inflammatory drug. However its property to stimulate adrenal catecholamine release has been used [9], and it is still used as a tool for the diagnosis of pheochromocytoma [10, 12]. Blood pressure response to glucagon in a patient with pheochromocytoma and the complete lack of response when the test was performed again after removal of the tumour is shown in Figure 1. Moreover, glucagon is now largely utilized for its hypotonic effect on the gut to facilitate X-ray examination of the digestive tract or competurized-axial tomography [13]. Until now, I have been aware of three cases of pheochromocytoma which have been recognized by chance as a consequence of a severe hypertensive crisis resulting from an injection of glucagon [14-16].

\section{Animal investigation can promptly bring answers to problems raised by clinical practice}

This proposal is respectful of the ideas of Claude Bernard who once wrote 'I consider hospitals as only the entrance to scientific medicine; they are the first field of observations which a physician enters, but the true sanctuary of medical research is a laboratory' [17]. It can be illustrated by the next example. Some years ago, with my colleagues A. Luyckx and J.C. Daubresse, we observed that peripheral plasma glucagon levels were usually grossly elevated in chronic renal insufficiency [18]. This finding was similar to preliminary data reported by other groups [19-20] and was clinically relevant since high glucagon levels may be involved in the pathogenesis of glucose intolerance so frequently found in chronic renal failure [21]. A survey of the literature soon revealed that almost nothing was known on the renal handling of glucagon. We decided to approach the question experimentally and were soon able to demonstrate the primary role played by the kidney in the catabolism of glucagon [22]. In the isolated perfused dog kidney system, $40 \%$ of glucagon entering the kidney per unit of time is taken up by this organ and the capacity of the kidney to remove glucagon is quite impressive [23]. Bilateral kidney exclusion in the anaesthetized dog is followed by a rapid rise in circulating glucagon, the endogenous production of the hormone by the pancreas being unchanged $[24,25]$. These data strongly suggested that reduced glucagon uptake by the kidney is responsible for the elevated circulating glucagon levels observed in renal failure.

To be fair, however, I have to mention that things are not as simple as they look at first glance. Under chronic conditions and as shown by Kuku et al. [26, 27] and by Valverde [28], the circulating pattern of the various components of plasma glucagon is modified by renal failure with a particular accumulation, not only of the $3500 \mathrm{dal}-$ ton component, but also of the 9000 dalton component which is likely to be related to proglucagon. Moreover, as recently demonstrated in our Laboratory by Loly et al., nephrectomy in the dog also significantly reduced the peripheral removal of glucagon, a phenomenon which suggests that the kidney exerts some control on the peripheral uptake of the hormone, an effect whose mechanism is, until now, entirely unknown [29, 30]. Therefore, the high glucagon levels observed in severe renal insufficiency are likely to result from both decreased renal catabolism and reduced peripheral uptake.

\section{Fruitfulness of interdisciplinary collaboration}

My third proposal will justify the title From plant physiology to human metabolic investigations. It illustrates, the fruitfulness of interdisciplinary collaboration with its breaking of some of the artificial frontiers that exist between the natural sciences.

In 1972, M.Lacroix and F. Mosora of the Department of Physics of the University of Liège, broke one of these frontiers. They came to our Laboratory and explained that some natural glucose they had analyzed had a slightly unusual enrichment in ${ }^{13} \mathrm{C}$ and asked whether we could foresee some use of this property for metabolic investigations in man. At that time, I was barely aware of the existence of the ${ }^{13} \mathrm{C}$ isotope and knew nothing about variations in its natural abundance.

\section{Isotopes of carbon and their measurement}

There are no less than eight isotopes of carbon (Table 1): ${ }^{9} \mathrm{C},{ }^{10} \mathrm{C},{ }^{11} \mathrm{C},{ }^{15} \mathrm{C}$ are all radioactive and have half-lives below $30 \mathrm{~min}$. Some, such as ${ }^{9} \mathrm{C}$ and ${ }^{16} \mathrm{C}$, are extremely short-lived radionuclides. Isotope ${ }^{11} \mathrm{C}$, produced in cyclotrons by a $\mathrm{p}, \alpha$ reaction on natural nitrogen, is progressively being used to label substrates for metabolic and imaging investigations in man. In

Table 1. Isotopes of carbon

\begin{tabular}{lllllllll}
\hline Isotopes & ${ }^{9} \mathrm{C}$ & ${ }^{10} \mathrm{C}$ & ${ }^{11} \mathrm{C}$ & ${ }^{12} \mathrm{C}$ & ${ }^{13} \mathrm{C}$ & ${ }^{14} \mathrm{C}$ & ${ }^{15} \mathrm{C}$ & ${ }^{16} \mathrm{C}$ \\
\hline Half-life & 127 & 19.45 & $\begin{array}{l}20.3 \\
(\mathrm{~min})\end{array}$ & stable & $\begin{array}{l}5730 \\
\text { (years) }\end{array}$ & $\begin{array}{l}2.45 \\
(\mathrm{~s})\end{array}$ & $\begin{array}{l}0.75 \\
(\mathrm{~s})\end{array}$ \\
$\begin{array}{l}\text { Natural } \\
\begin{array}{l}\text { abun- } \\
\text { dance (\%) }\end{array}\end{array}$ & - & - & - & \pm 98.9 & \pm 1.1 & $10^{-10}$ & - & - \\
\hline
\end{tabular}




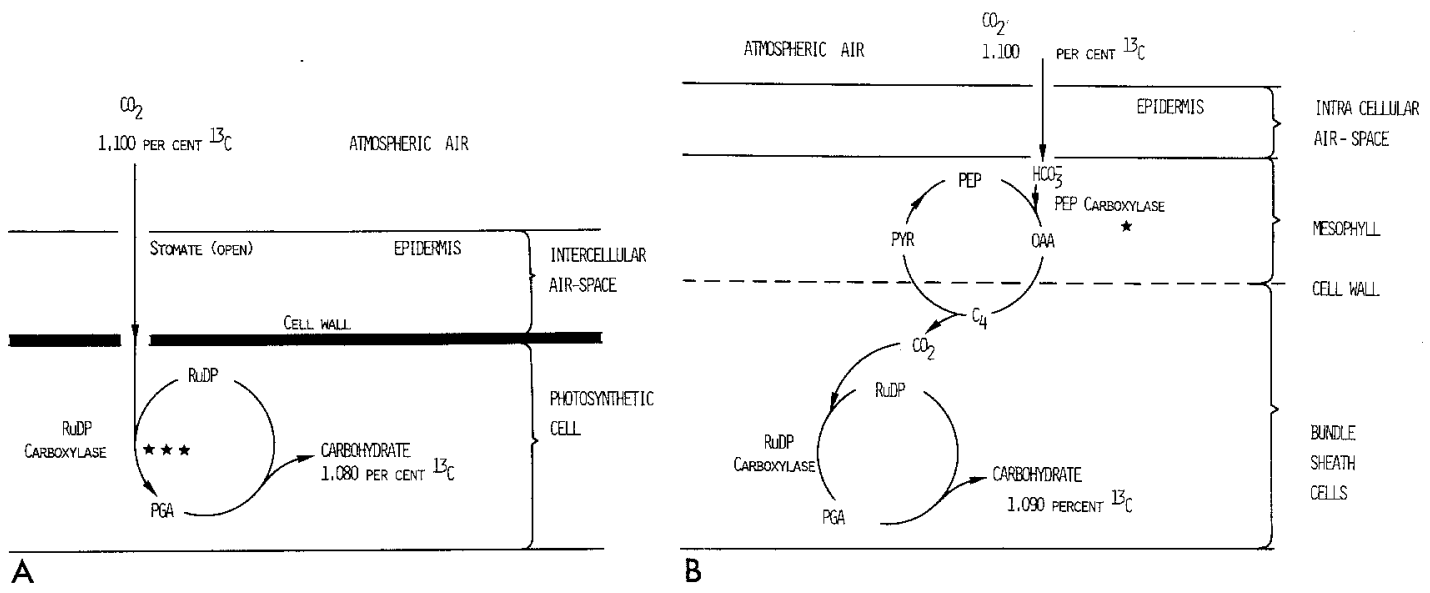

Fig. 2. A 'Three-carbon' photosynthetic pathway showing Calvin-Benson cycle with significant isotopic effect $\left({ }^{* *}\right)$ favouring ${ }^{12} \mathrm{C}$. B 'Four-carbon' photosynthetic pathway (Hatch-Slack pathway) with minor isotopic effect $\left(^{*}\right.$ ) favouring ${ }^{12} \mathrm{C}$. $\mathrm{PYR}=$ pyruvate; $\mathrm{PEP}=$ phosphoenolpyruvate; $\mathrm{OAA}=$ oxaloacetate; RuDP = ribulose diphosphate; $\mathrm{PGA}=$ phosphoglycerate. [Modified from Björkman and Berry - 52]
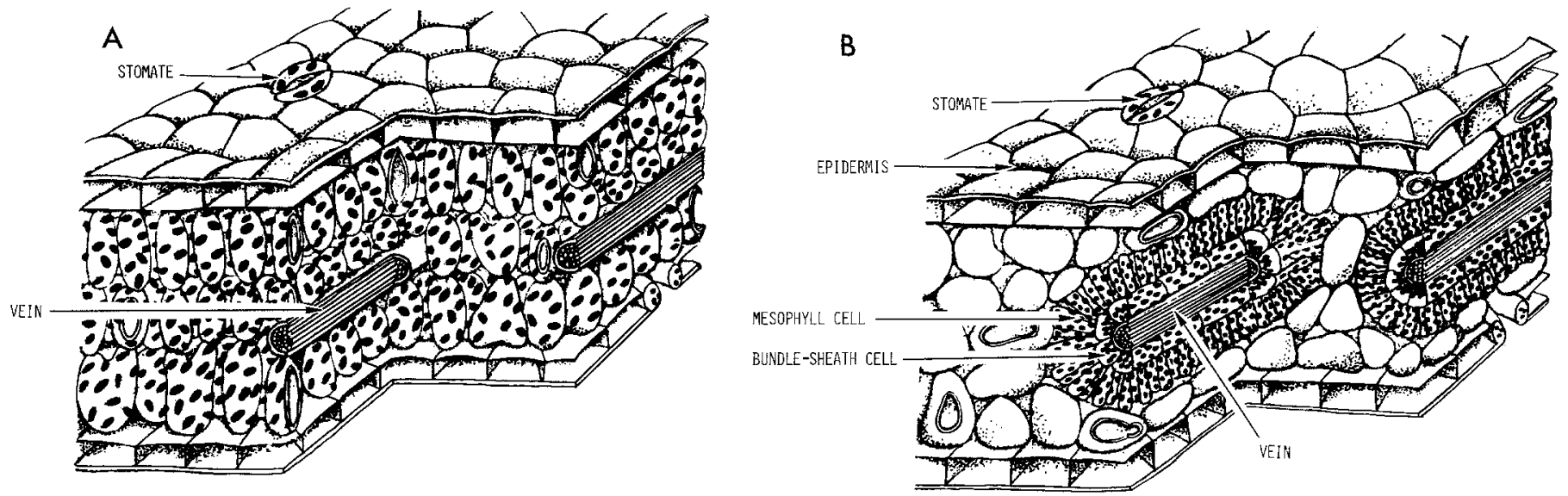

Fig.3 A and B. Schematic drawing of a leaf in $\mathbf{A}$ a $\mathrm{C}_{3}$-plant and $\mathbf{B}$ a $\mathbf{C}_{4}$-plant. Reproduced from "High efficiency photosynthesis" by Björkman and Berry [53]

contrast, ${ }^{14} \mathrm{C}$, with its very long half-life, has been used for many years as a metabolic tracer in biology and medicine, but this long half-life is often an ethical limitation to its use in man. Let us focus on the two stable, non-radioactive, isotopes of carbon. Their respective natural abundance is approximately $99 \%$ for ${ }^{12} \mathrm{C}$ and $1 \%$ for ${ }^{13} \mathrm{C}$ and indeed the word "approximately" is of importance since the variations we have to consider are extremely small at these approximative values. ${ }^{13} \mathrm{C}$ differs from ${ }^{12} \mathrm{C}$ by one unit of mass and sophisticated instruments are needed to detect the very small changes in the natural abundance of these two isotopes. In practice, one makes use of "isotope ratio" mass spectrometers, in which one compares the ${ }^{13} \mathrm{C} /{ }^{12} \mathrm{C}$ ratio in a sample to that in a given standard [31,32]. In so doing, the results are expressed in $\delta^{13} \mathrm{C}$ which is the ratio of these ratios [33]:

$\delta{ }^{13} \mathrm{C}=10^{3} \times\left[\frac{\left({ }^{13} \mathrm{C} /{ }^{12} \mathrm{C}\right) \text { sample }}{\left({ }^{13} \mathrm{C} /{ }^{12} \mathrm{C}\right) \text { standard }}\right]-1$

The usual reference standard is calcite in a specimen of Belimnitella americana found in the Peedee Formation in South Carolina, USA, and abbreviated to PDB. The
${ }^{13} \mathrm{C}$ content of most biological specimens is slightly less than in PDB; as a consequence their $\delta{ }^{13} \mathrm{C}$ has a negative value. In our studies, we have made use of our own standard, which has a value of -28.5 per mil $(\%)$ relative to the usual PDB-1 Chicago standard. In relation to that standard, the $\delta^{13} \mathrm{C}$ values of the specimens we have analyzed are usually positive $(+)$. The $\delta{ }^{13} \mathrm{C}$ of atmospheric $\mathrm{CO}_{2}$, expressed against our standard, is approximately $22 \%$, a value which corresponds to an absolute abundance of about $1.100 \%{ }^{13} \mathrm{C}$. The reason of the enrichment in ${ }^{13} \mathrm{C}$ of some natural sugars is found in selective isotopic effects occurring during photosynthesis. We now break another frontier and enter plant physiology.

\section{Isotopic discrimination during photosynthesis}

In the majority of plants, called the "three carbon carboxylic acid plants" or $\mathrm{C}_{3}$-plants, photosynthesis proceeds according to a metabolic sequence which is summarized in Figure $2 \mathrm{~A}$. Carbon dioxide penetrates the leaves through the stomates (Fig. $3 \mathrm{~A}$ ), dissolves in the cytosol and is used to carboxylate one molecule of ribu- 


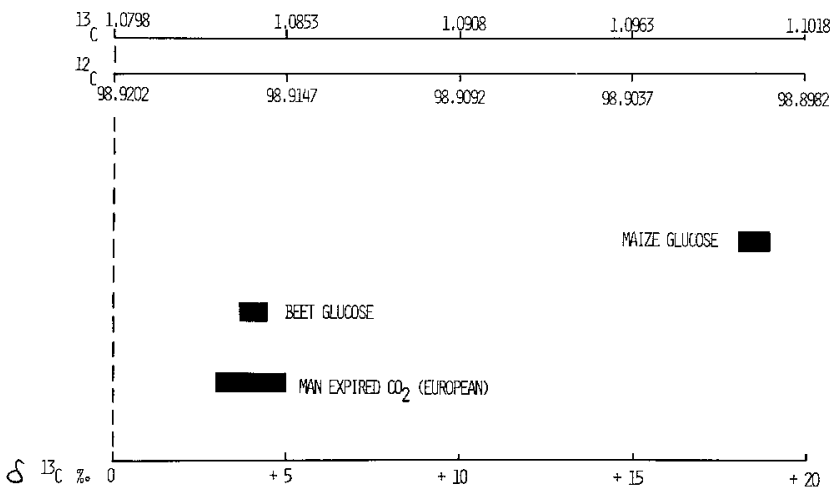

Fig. 4. ${ }^{13} \mathrm{C}$ and ${ }^{12} \mathrm{C}$ content of beet and maize glucose compared with the ${ }^{13} \mathrm{C}$ and ${ }^{12} \mathrm{C}$ content of human expired air $\mathrm{CO}_{2}$. The upper scale gives the absolute percentage values of ${ }^{13} \mathrm{C}$ and ${ }^{12} \mathrm{C}$; the lower scale shows the corresponding values expressed according to the formula of Craig [33] (see text) and using a personal standard [37]. The value of this standard is $-28.5 \%$ relative to the usual PDB-1 Chicago standard, or $0.7 \%$ relative to the National Bureau of Standards sample 21 (NBS 21)

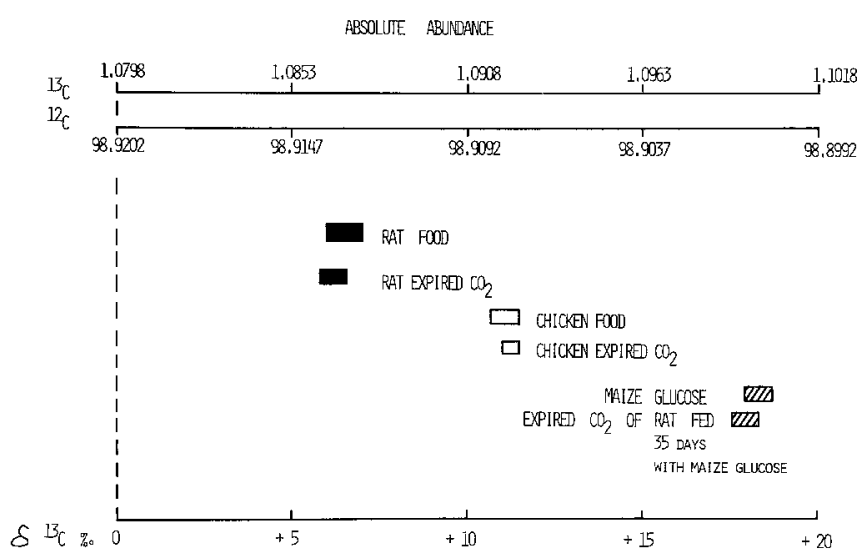

Fig. 5. ${ }^{13} \mathrm{C}$ and ${ }^{12} \mathrm{C}$ content of three nutrients: rat food, chicken food or glucose prepared from maize. The $\mathrm{CO}_{2}$ expired by rat or chicken has a ${ }^{13} \mathrm{C} /{ }^{12} \mathrm{C}$ ratio similar to the ratio of these isotopes in their respective food. After 35 days of feeding with maize glucose, the rat expires $\mathrm{CO}_{2}$ which has the same ${ }^{13} \mathrm{C} /{ }^{12} \mathrm{C}$ ratio as that present in the fed glucose. For scales, see legend to Figure 4

$c_{3}$ PLANTS ('LOW $13 \mathrm{C}$ ')

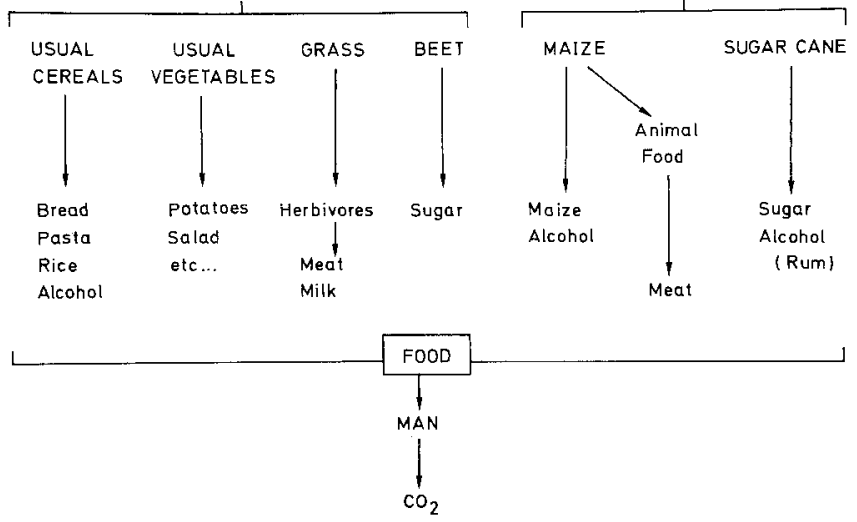

Fig. 6. Examples of components of human food derived from plants having the $\mathrm{C}_{3}$ or $\mathrm{C}_{4}$ pathways of photosynthesis lose diphosphate to produce two molecules of 3-phosphoglycerate. Thereafter, photosynthesis proceeds according to the cycle described by Calvin (see review in 34). Isotopic discrimination occurs at the level of this initial carboxylation step in which ${ }^{12} \mathrm{CO}_{2}$ rather than ${ }^{13} \mathrm{CO}_{2}$ is preferably incorporated. As a consequence, the sugars made by these plants are slightly depleted in ${ }^{13} \mathrm{C}$, and enriched in ${ }^{12} \mathrm{C}$, when compared with the $\mathrm{CO}_{2}$ they have used for their photosynthesis. In absolute terms, this depletion represents about 0.02 of a percent, a small, but very consistent isotopic effect [35].

In other plants, about $10 \%$ of those existing in our world, mainly in tropical regions, photosynthesis follows a more complicated pathway which has been elucidated by Hatch and Slack [36] and is illustrated by Figure $2 \mathrm{~B}$. Carbon dioxide enters the leaves through the stomates (Fig. 3 B) and then penetrates an outer layer of cells, called the mesophyll cells, where it dissolves and equilibrates with bicarbonate. Bicarbonate and phosphoenolpyruvate react, under the control of phosphoenolpyruvate carboxylase, to form oxaloacetate from which the C4-compounds, malic acid and aspartic acid are formed. For that reason, these plants are called the $\mathrm{C}_{4}$-plants. These four-carbon acids are then transported into other cells, called the "bundle sheath cells", which are located further inside the leaves (Fig. 3 B). There, the four-carbon acids are decarboxylated; pyruvate is regenerated and returns to the mesophyll cells. Carbon dioxide, now in a closed compartment in the bundle-sheath cells, is incorporated as in the $\mathrm{C}_{3}$-plants to form 3-phosphoglycerate. As far as the isotopic effects are concerned, a very small effect favouring ${ }^{12} \mathrm{C}$ occurs at the phosphoenolpyruvate carboxylase step, but this effect is smaller than that in the $\mathrm{C}_{3}$-plants. Since the bundle sheath cells apparently act as a closed compartment, exchange of $\mathrm{CO}_{2}$ with other cells or loss of gas to the atmosphere does not occur. As a consequence, the decarboxylated carbon is quantitatively refixed by the ribulose diphosphate carboxylase reaction without further isotopic discrimination.

As a result of these two distinct pathways of photosynthesis, sugars made by these two types of plants differ distinctly in their ${ }^{13} \mathrm{C}$ content (Fig. 4). If we compare the ${ }^{13} \mathrm{C}$ content of glucose prepared from maize (a $\mathrm{C}_{4}$-plant) or beet (a $\mathrm{C}_{3}$-plant), we observe that their ${ }^{13} \mathrm{C}$ abundance is unequivocally different (relatively high in the former, relatively low in the latter). These differences, although impressive when expressed in $\delta^{13} \mathrm{C}$, are indeed extremely small when considered in absolute terms (upper scale of Fig. 4): a few hundredths of a percent [37].

\section{Food chain and variations in ${ }^{13} \mathrm{C}$ of natural sugars}

Sugars made by photosynthesis are at the origin of the food chain and, as shown by Lacroix and Mosora, the natural abundance of ${ }^{13} \mathrm{C}$ in a given animal will reflect the natural abundance of ${ }^{13} \mathrm{C}$ in its diet [38]. If we feed 


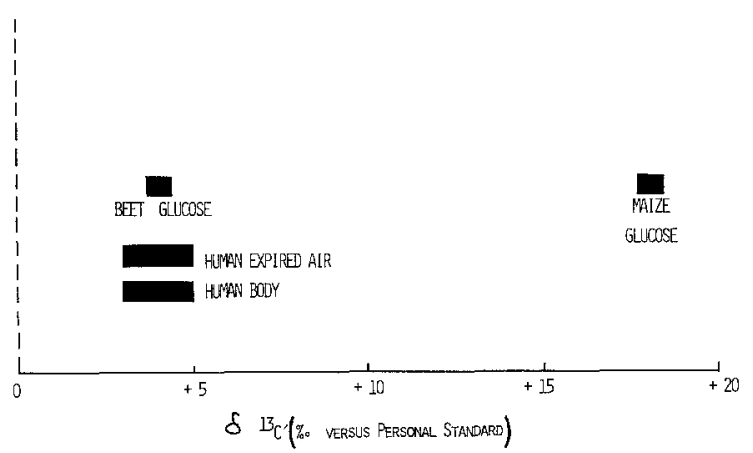

Fig. 7. European man has $a^{13} \mathrm{C} /{ }^{12} \mathrm{C}$ ratio in the body [54] or in expired air [37] which is similar to that of glucose prepared from beet sugar [37]. In contrast, the $\delta^{13} \mathrm{C}$ of maize glucose (see legend to Fig. 4) is significantly higher [37]

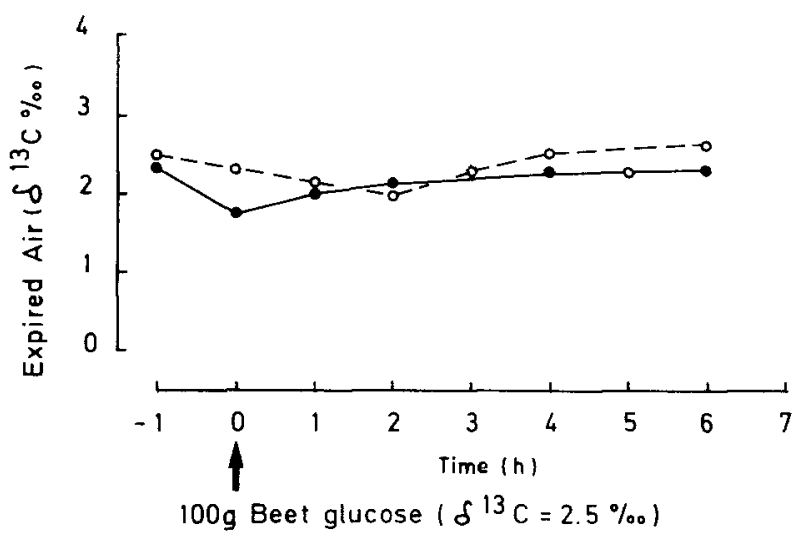

Fig. 8. Lack of significant changes in expired air $\delta^{13} \mathrm{C}$ carbon dioxide following a $100-\mathrm{g}$ oral load of glucose derived from beet sugar. The glucose batch was selected to match appoximately the ${ }^{13} \mathrm{C} /{ }^{12} \mathrm{C}$ ratio existing in the expired air of the two subjects investigated under basal conditions. (Data from N. Pallikarakis, Thesis, University of Liège, 1980)

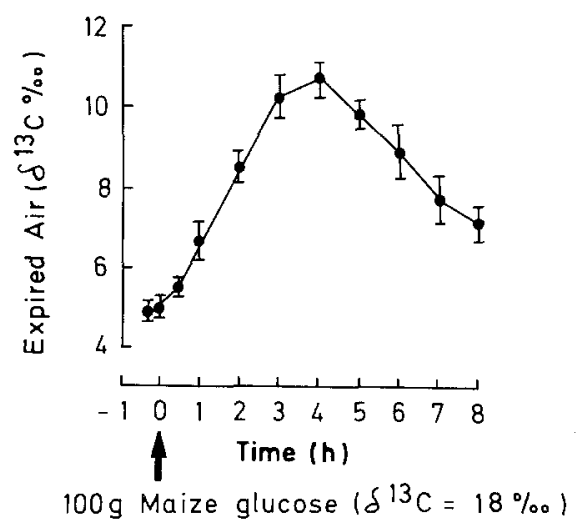

Fig.9. In contrast to the data reported in Figure 8, a significant enrichment in ${ }^{13} \mathrm{C}\left(\delta^{13} \mathrm{C}\right)$ is observed in expired air carbon dioxide when the $100-\mathrm{g}$ oral glucose load is prepared from maize sugar. Results are expressed as mean $\pm \operatorname{SEM}(n=8)$

rats with commercial rat food having, a $\delta^{13} \mathrm{C}$ of $6-7 \%$, the $\delta{ }^{13} \mathrm{C}$ in their expired $\mathrm{CO}_{2}$ has approximately the same value (Fig. 5). Chicken food, prepared partly from maize, has a higher ${ }^{13} \mathrm{C}$ content, and the ${ }^{13} \mathrm{C}$-content of the $\mathrm{CO}_{2}$ expired by chicken on this diet is correspond-
Table 2. Measurement of ${ }^{13} \mathrm{C}$ abundance in expired air

Precision of the assay $0.1 \%$

Reproducibility $(n=10) \mathrm{SD}=0.12 \%$

Within variance: 44 subjects, two measurements, 15 -min intervals, $\mathrm{SD}=0.21 \%$

Long-term variations: Six subjects, four to five measurements over 2 months, $\mathrm{SD}=0.25 \% 0$

ingly higher. Now, if we take rats, initially fed with their regular rat food, and feed them for 35 days only with glucose prepared from maize, we observe that they equilibrate their expired $\mathrm{CO}_{2}$ in such a way that it becomes significantly enriched in ${ }^{13} \mathrm{C}$. In summary, the ${ }^{13} \mathrm{C} /{ }^{12} \mathrm{C}$ ratio in animal body carbons (and, as a consequence, that in expired $\mathrm{CO}_{2}$ ) reflects the natural abundance of these two isotopes of carbon in the diet of the animals.

The food-chain of European man is derived mainly from $\mathrm{C}_{3}$-plants (Fig. 6): so are the cereals which provide bread, pasta and rice, the vegetables such as potatoes, salads, etc. ..., and so is meat and milk of herbivore animals which eat grass, and so on. Only a minor part of our food-chain originates from $\mathrm{C}_{4}$-plants having the Hatch-Slack pathway; such is the case when we eat sugar or sweets made from sugar cane or drink rum made from fermented sugar cane, when we eat maize or corn flakes, or more indirectly, for instance, a piece of chicken fed mainly on maize. As a consequence, the natural abundance of ${ }^{13} \mathrm{C}$ in the average European body carbon is on the low side of the scale, as is reflected by a $\delta{ }^{13} \mathrm{C}$ in our expired air carbon dioxide of about 4 per mil, which contrasts markedly with the $\delta^{13} \mathrm{C}$ of maize glucose which is about 18 per mil (Fig. 7). Can we make use of this property for metabolic studies in man?

\section{Naturally-labelled ${ }^{13} \mathrm{C}$-glucose and metabolic studies in man}

In a certain sense, we can consider that the natural abundance of ${ }^{13} \mathrm{C}$ in the body carbon containing molecules has "prelabelled" the pools of these molecules with ${ }^{13} \mathrm{C}$ atoms. The $\delta{ }^{13} \mathrm{C}$ of expired air $\mathrm{CO}_{2}$ is fairly constant if the usual pattern of alimentation is maintained. The within-variance for two measurements performed twice, at 15 -min intervals, in 44 subjects is only $0.21 \%$ (Table 2). Similarly, long-term variations are small. The average of four to five measurements performed in six subjects fasted overnight examined weekly over a 2 -month period is remarkably stable with a mean standard deviation of only $0.25 \%$. If we give to resting normal subjects a $100-\mathrm{g}$ glucose load, prepared from beet sugar (which has about the same natural abundance of ${ }^{13} \mathrm{C}$ as that present in the body), we do not modify significantly the $\delta^{13} \mathrm{C}$ in $\mathrm{CO}_{2}$ expired during the next 6-7 h (Fig. 8). This observation is important since it indicates that an oral glucose load per se does not induce detectable isotopic effects in vivo reflected in expired $\mathrm{CO}_{2}$. In contrast, if we give an identical glucose 


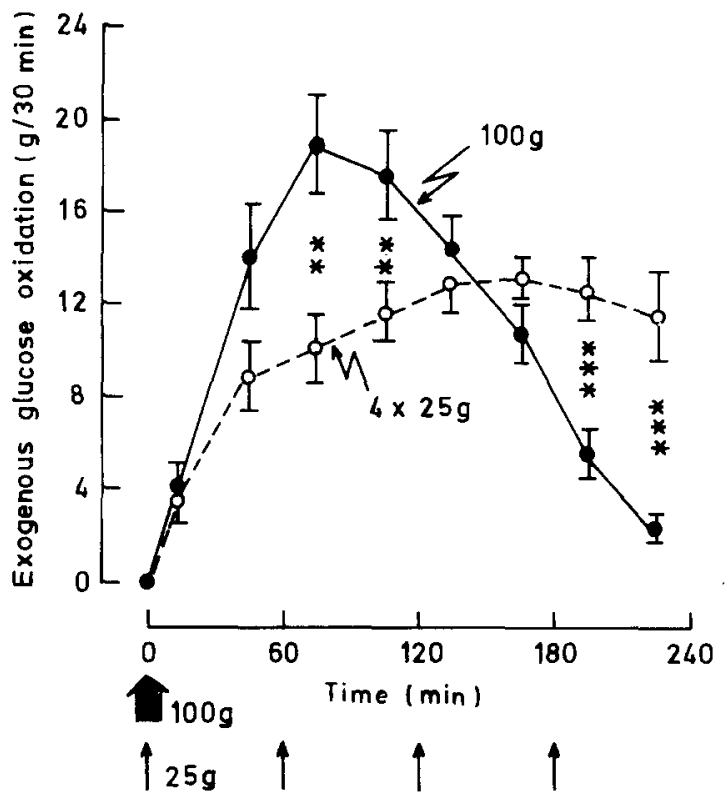

Fig. 10. Exogenous glucose oxidation during prolonged-duration moderate-intensity exercise (treadmill exercise for $255 \mathrm{~min}$ at $45 \%$ $\mathrm{VO}_{2} \max$ ). In all instances, the first load of glucose was given after $15 \mathrm{~min}$ adaptation to exercise. Four subjects received $100 \mathrm{~g}$ glucose at time $0(-)$ ) or for times $25 \mathrm{~g}$ at times indicated by the thin arrows $(\mathrm{O}----O)$. Results expressed as mean \pm SEM. Statistical comparison between the two experimental conditions: $* *=p<0.02$ and $* * *=p<0.01$. [Data from Pirnay et al. 48]

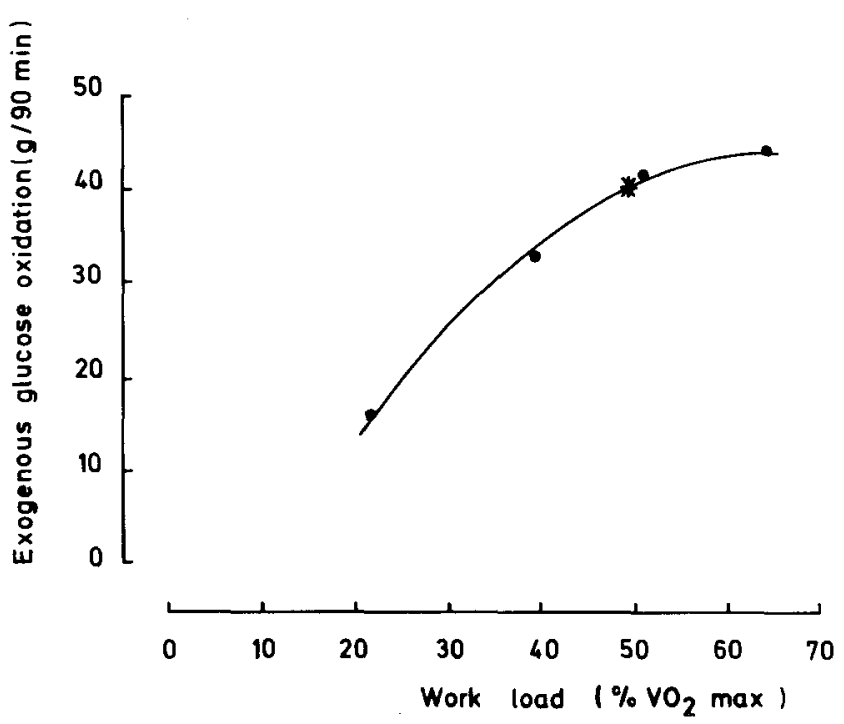

Fig. 11. Exogenous glucose oxidation during exercise of various intensities. Four healthy volunteers were submitted on four different days to a $105 \mathrm{~min}$ treadmill exercise at $22,39,51$ and $64 \%$ of their individual $\mathrm{VO}_{2} \mathrm{max}$. After $15 \mathrm{~min}$ adaptation to exercise, they received $100 \mathrm{~g}$ naturally labelled ${ }^{13} \mathrm{C}$-glucose. Between $22 \%$ and $51 \%$ of $\mathrm{VO}_{2}$ max, exogenous oxidation linearly correlated with the relative workload. Between 51 and $64 \% \mathrm{VO}_{2}$ max, exogenous glucose oxidation tends to plateau. [Data from Pirnay et al. 49]

load but use a preparation from maize sugar which is "naturally enriched" in ${ }^{13} \mathrm{C}$, we observe the appearance of excess ${ }^{13} \mathrm{C}$ atoms in expired air $\mathrm{CO}_{2}$ reflecting oxidation of part of the given glucose load [37] (Fig.9). If we measure simultaneously the absolute amounts of ex-

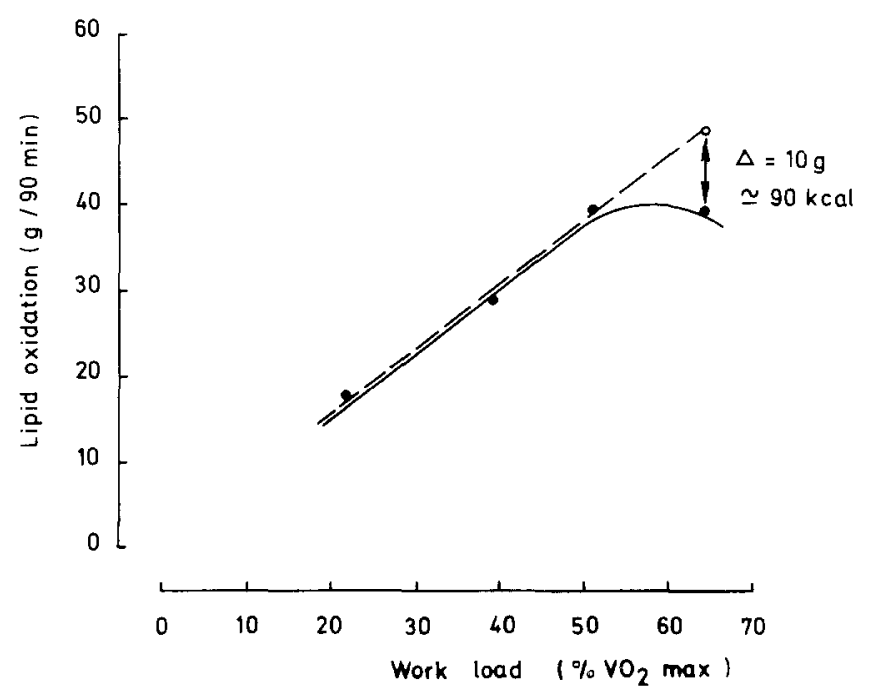

Fig. 12. Lipid oxidation during exercise of various intensities. Proto$\mathrm{col}$ is described in legend to Figure 11. Between $22 \%$ and $51 \% \mathrm{VO}_{2}$ max, lipid oxidation was correlated with the relative work load. Between $51 \%$ and $64 \% \mathrm{VO}_{2}$ max, lipid oxidation tended to level off

pired air $\mathrm{CO}_{2}$ using conventional procedures, we can calculate the net amounts of exogenous glucose which have been converted to expired air $\mathrm{CO}_{2}[39,40]$. At rest, these amounts have been found to average $28-30 \mathrm{~g}$ in $7 \mathrm{~h}$ after ingestion of a $100-\mathrm{g}$ glucose load $[39,40]$. These figures represent an underestimation of the real oxidation of exogenous glucose (1) because of the possible interconversion of substrates $[41,42](2)$ because of the incorporation of some of the $\mathrm{CO}_{2}$ produced into carboxylation reactions and (3) because of the well-known slow equilibration of the $\mathrm{CO}_{2}$-bicarbonate pool [43]. For these reasons, we directed our next studies to the investigation of exogenous glucose utilization in muscular exercise, a condition in which the overall orientation of metabolism towards catabolism and the great enhancement of respiratory ventilation considerably reduce the influence of the above-mentioned factors.

\section{The fate of glucose ingested during exercise}

A preliminary step for these investigations was to demonstrate that exercise per se does not modify significantly the $\delta{ }^{13} \mathrm{C}$ of expired air [44]. It is sometimes claimed in the literature that glucose given orally during exercise is a poorly available metabolic substrate $[45$, 46]. Our data do not support such statements. Ingested after $15 \mathrm{~min}$ of adaptation to exercise in healthy subjects exercising for $4 \mathrm{~h}$ at about $45 \%$ of their $\mathrm{VO}_{2 \max }$, a 100 -g glucose load is almost entirely oxidized with, as a consequence, a significant sparing of endogenous glucose [47]. The availability of a oral $100-\mathrm{g}$ glucose load is 
the same whether given after $2 \mathrm{~h}$ of exercise or shortly after initiation of exercise [44]. Moreover, split oral doses of glucose ( $25 \mathrm{~g}$ every hour) during a 4 -h exercise bout lead to oxidation of exogenous glucose which matched perfectly the amounts given (Fig. 10) [48]. The only condition in which we have observed a certain limitation on the availability of glucose given orally during exercise is that of an intense work load [49]. For exercises ranging between 20 and $50 \% \mathrm{VO}_{2 \max }$ for $90 \mathrm{~min}$, exogenous glucose oxidation increases as the work load increases; above $50 \% \mathrm{VO}_{2 \max }$, there is a plateau in the oxidation of exogenous glucose (Fig. 11) and, as indirect calorimetry data show, lipid oxidation also plateau (Fig. 12). Thus, for these intensities of exercise, the bulk of extra energy needed has to come from endogenous carbohydrate stores.

\section{Exogenous glucose oxidation during exercise in diabetes}

When young, Type 1 (insulin-dependent) diabetic patients are submitted to a similar long-term $(4 \mathrm{~h})$, medium intensity ( $45 \% \mathrm{VO}_{2 \max }$ ), exercise, their ability to oxidize a 95-g oral glucose load is similar to that of normal subjects, providing that they receive adequate insulin (Table 3). This observation has led us to propose that well-controlled Type 1 diabetic patients, with ideal body weight who want to exercise, can best obtain energy and avoid hypoglycaemia by simply ingesting glucose-containing drinks during exercise itself [50].

I hope that these few examples taken from the many studies we have performed using "naturally labelled ${ }^{13} \mathrm{C}$-glucose" have convinced you of my proposal that the cooperative work of a team of physicists, exercise physiologists and physicians, all having learned a little bit of plant physiology, has been fruitful and has permitted us to draw conclusions interesting not only to physiologists but also to clinicians, and possibly to patients.

\section{Clinical practice cannot be dissociated from research}

My fourth point is that daily clinical practice cannot be dissociated from research. In other words, the spirit of research is an integral part of medical practice. The insufficiently known example of the physicians in the Warsaw ghetto in the last world-war is a tragic demonstration of this proposal. The situation was most dramatic in February 1942 in the Jewish Hospital CZYSTE in the Warsaw ghetto, where nazis had started to gather all Jews of the City. The Jewish Council of the City began to organize the life of the inhabitants. The daily caloric allowance was $600-800 \mathrm{kcal}$ per capita, consisting mainly of carbohydrates, a few lipids, and some vegetable proteins of poor nutritional quality. Typhus and tuberculosis had led to impressive mortality rates and malnutrition was dramatic. The medical team of the Jewish Hospital was directed by an anatomopatholo-
Table 3. Exogenous glucose oxidation during exercise in healthy controls and diabetic subjects

\begin{tabular}{ll}
\hline $\begin{array}{l}\text { Exogenous glucose given }(\mathrm{g}) \\
\text { Exogenous glucose oxidized during } 4 \mathrm{~h} \\
\text { of exercise }(\mathrm{g}) \\
\text { Healthy control subjects }(n=7)\end{array}$ \\
$\begin{array}{l}\text { Well-controlled Type } 1 \text { diabetic subjects } \\
(n=5)\end{array}$ \\
$\begin{array}{l}\text { Poorly controlled Type } 1 \text { diabetic subjects } \\
(n=5)\end{array}$
\end{tabular}

gist, Dr. Stein. He and his collegues were engaged in an hopeless battle to delay the unavoidable death in their many patients. Themselves and their own families were suffering in their bodies and their souls. Basic instrumentation and medication were badly lacking. The outside world was unaware of their condition and the few who were told did not believe that such an horror was happening. Under these dramatic conditions, an exceptional multidisciplinary investigation on the "hunger disease" was designed and carried out. Its results have been published in French and in Polish by Dr. Emil Apfelbaum in 1946 in Warsaw [51] and more recently translated into English [52]. The study started in February 1942 and lasted, for obvious reasons, 5 months only. Among the various facets of the hunger disease (clinical aspects in adults and children, pathophysiology of the circulatory system, peripheral and blood marrow disorders, ocular disturbances, pathological anatomy ...) investigated are some metabolic studies. The oral glucose tolerance curve is markedly flattened in hunger disease and real reactive hypoglycemia is present. In the insulin tolerance test in healthy individuals, hypoglycemia is preceded by transient hyperglycemia; we now know that this results from stimulation of hepatic glycogenolysis by the glucagon contaminent of the rather impure insulin preparations of those times; in hunger disease, glycogen stores are depleted and this hyperglycemic peak is not observed. The human aspect of the study is distressful. Dr. Apfelbaum wrote in French and I have translated: "Death from long-lasting hunger is like a candle burning out slowly: life disappears progressively, without visible steps. The hungry person becomes lazy, miserly hoarding the remains of his belongings, the last of his vital energy; he spends the minimum". Between 1942 and 1944, most of the physicians who had participated in the study died either in concentration camps or in the ruins of the ghetto destroyed by fire by the Nazis after the insurrection. One of the few survivors, Dr. Emil Apfelbaum was deported to a camp, liberated by the Allied Forces but ultimately died on January 12, 1946 after having been able to edit the book, given to me by his son Dr. Marian Apfelbaum from Paris and in which I have 
found this information. Is this not a moving demonstration that medical care and medical research are really interwoven?

Acknowledgments. I am greatly indebted to the European Association for the Study of Diabetes and to the Paul Neuman Foundation for the honour of having been selected as 1984 Claude Bernard Lecturer. This gives me the opportunity to give credit to my mentors Z. M. Bacq, M. Chèvremont, M. Florkin, A. Nizet, J. Roskam and H. Van Cauwenberge, all from the University of Liège, who have exerted a determinant influence on my scientific formation and career. Outside the borders of Belgium, A.E. Renold (Geneva), R.H. Unger (Dallas) and L. Orci (Geneva) have greatly influenced me through their example and I thank them for their long-lasting friendships and scientific collaboration. Alfred Luyckx, my scientific companion and collegue for more than 20 years, deserves special credit; he knows my gratitude and my friendship. I also wish to acknowledge the names of all those in Belgium (J.L.Carpentier, J.M.Crielaard, J.C.Daubresse, A.Fossion, U.Gaspard, J.Gérard, Ph.Henrivaux, B.Jandrain, G.Krzentowski, M. Lacroix, M. Lecomte, J. Loly, F. Mosora, A. Nemery, F.Pirnay, A.Scheen and E. Verdin) and those from abroad (G. Federspil, D. Giugliano, F. Massi-Benedetti $\uparrow$, G. Paolisso and S. Tamburrano from Italy; J.E.Campillo, M.Castillo and M.D.Torres from Spain; N.Pallikarakis from Greece; E. Mendoza from Panama and D.de la Torre and G. Lopez-Habib from Mexico) with whom I have been fortunate to collaborate. I am also indebted to the team of skilled technicians, secretaries and nurses without whom my work would have been impossible, and particularly C. Borremans, Y.Claessens, C.Jaminet, R. Lallemand, M.E. Loumaye, M. Marchand, A. M. Rinaldi, A. Rombaux, M.Scheen-Lavigne, H. Thoumsin, J. Thoumsin and E. VaessenPetit.

\section{References}

1. Robin ED (1979) Claude Bernard and his historical milieu. In: Robin ED (ed) Claude Bernard and the internal environment. Marcel Dekker, New York, Basel, pp 1-15

2. Helmer OM, Kirtley WR, Ridolfo AS (1957) Clinical and metabolic changes induced by glucagon in patients with rheumatoid arthritis. J Lab Clin Med 50: 824 (Abstract)

3. Lefèbvre P (1960) Influence du glucagon sur l'oedème local provoqué chez le rat par certaines substances phlogistiques. CR Soc Biol 155: 410-412

4. Lefèbvre P, Van Cauwenberge H (1962) Glucagon et réactions oedémateuses du rat. Arch Int Pharmacodyn Ther 138: 222-229

5. Lefèbvre $P$ (1961) Influence de la surrénalectomie sur l'inhibition par le glucagon des réactions oedémateuses du rat. CR Soc Biol 155: 410-412

6. Lefèbvre P, Palem-Vliers M, Van Cauwenberge H (1961) Le glucagon stimule-t-il le cortex surrénalien du rat? CR Soc Biol 155: $1726-1728$

7. Lefèbvre P, Dresse A (1961) Influence du glucagon sur le taux des catécholamines surrénaliennes chez le rat. CR Soc Biol 155: 412-414

8. Lefèbvre P (1962) Glucagon et inflammation expérimentale. Ann Endocrinol 23:275-279

9. Scian LF, Westermann CD, Verdesca AS, Hilton JG (1960) Adreno-cortical and medullary effects of glucagon. Am J Physiol 199: $867-870$

10. Lawrence AM (1965) A new provocative test for pheochromocytoma. Ann Intern Med 63: 905-906

11. Lefèbvre P, Cession-Fossion A, Luyckx AS (1966) Glucagon test for pheochromocytoma. Lancet 2: 1366

12. Lefèbvre P, Luyckx AS (1983) Glucagon and catecholamines. In: Lefèbvre P (ed) Glucagon. Handbook of experimental pharmacology 66, II, Springer, Berlin Heidelberg New York Tokyo, pp 536-543
13. Diamant D, Picazo J (1983) Spasmolytic action and clinical use of glucagon. In: Lefèbvre P (ed) Glucagon. Handbook of experimental pharmacology 66, II, Springer-Verlag, Berlin Heidelberg New York Tokyo, pp 611-643

14. Beggs I (1978) Pheochromocytoma diagnosed during a barium meal. Br J Radiol 51: 918

15. Geelhoed GW (1980) CAT scans and catecholamines. Surgery 87: 719-720

16. McLoughlin M, Langer B, Wilson DR (1981) Life-threatening reaction to glucagon in a patient with pheochromocytoma. Radiology 140: 841-842

17. Bernard C (1952) Introduction à la médecine expérimentale. Flammarion, Paris

18. Daubresse JC, Lerson G, Plomteux G, Rorive G, Luyckx AS, Lefèbvre PJ (1976) Lipids and lipoproteins in chronic uremia. A study of the influence of regular haemodialysis. Eur J Clin Invest 6: $159-166$

19. Assan R (1972) In vivo metabolism of glucagon. In: Lefèbvre PJ, Unger RH (eds) Glucagon: molecular physiology, clinical and therapeutic implications. Pergamon, Oxford New York, pp 45-59

20. Bilbrey GL, Faloona GR, White MG, Knochel JP (1974) Hyperglucagonemia of renal failure. J Clin Invest 53:841-847

21. Jaspan JB, Polonsky KS, Rubenstein AH (1983) Glucagon and renal insufficiency. In: Lefèbvre PJ (ed) Glucagon. Handbook of experimental pharmacology 66, II, Springer, Berlin Heidelberg New York Tokyo, pp 477-489

22. Lefèbvre PJ, Luyckx AS, Nizet AH (1974) Renal handling of endogenous glucagon in the dog: comparison with insulin. Metabolism 23: 753-761

23. Lefèbyre PJ, Luyckx AS, Nizet AH (1976) Independence of glucagon and insulin handling by the isolated perfused dog kidney. Diabetologia 12: 359-365

24. Lefèbvre PJ, Luyckx AS (1975) Effect of acute kidney exclusion by ligation of renal arteries on peripheral plasma glucagon levels and pancreatic glucagon production in the anesthetized dog. Metabolism 24: 1169-1176

25. Lefèbvre PJ, Luyckx AS (1976) Plasma glucagon after kidney exclusion: experiments in somatostatin-infused and in eviscerated dogs. Metabolism 25: 761-768

26. Kuku SF, Zeidler A, Emmanouel DS, Katz AI, Rubenstein AH, Levin NW, Tello A (1976) Heterogeneity of plasma glucagon patterns in patients with chronic renal failure and diabetes. J Clin Endocrinol Metab 42: 173-176

27. Kuku SF, Jaspan JB, Emmanouel DS, Zeidler A, Katz AI, Rubenstein AH (1976) Heterogeneity of plasma glucagon circulating components in normal subjects and patients with chronic renal failure. J Clin Invest 58: 742-750

28. Valverde I (1983) Heterogeneity of circulating glucagon and glucagon-like immunoreactivity. In: Lefèbvre PJ (ed) Glucagon. Handbook of experimental pharmacology 66, II, Springer, Berlin Heidelberg New York Tokyo, pp 223-244

29. Loly J, Luyckx AS, Lefèbvre PJ (1984) Renal control of cephalic and intestinal removal of glucagon in the anesthetized dog. Horm Metab Res 16: 308-310

30. Loly J, Luyckx AS, Lefèbvre PJ (1984) Renal control of the cephalic and intestinal uptake of glucagon in the anesthetized dog. Diabetes 33 (Suppl1): $51 \mathrm{~A}$

31. Nier A (1947) A mass spectrometer for isotope and gas analysis. Rev Sci Inst 18: 398-411

32. McKinney C, McCrea J, Epstein S, Allen H, Urey H (1950) Improvements in mass spectrometry for the measurement of small differences in isotope abundance ratios. Rev Sci Inst 21: 724-730

33. Craig $H$ (1957) Isotopic standards for carbon and oxygen and correction factors for mass spectrometric analysis of $\mathrm{CO}_{2}$. Geoch Cosmoch Acta 12: 133-149

34. Gibbs M, Latzko E (eds) (1979) Photosynthesis II. Photosynthetic carbon metabolism and related processes. Springer, Berlin Heidelberg New York Tokyo (Encyclopedia of plant physiology, Vol. 6.)

35. Troughton $\mathrm{JH}(1979) \delta^{13} \mathrm{C}$ as an indicator of carboxylation reactions. In: Gibbs M, Latzko E (eds) Photosynthesis II. Photosyn- 
thetic carbon metabolism and related processes. Encylopedia of plant Physiology, Vol.6. Springer, Berlin Heidelberg New York, pp 140-149

36. Hatch M, Slack C (1966) Photosynthesis by sugar cane leaves: a new carboxylation reaction and the pathway of sugar formation. Biochem J 101: 103-111

37. Lacroix M, Mosora F, Pontus M, Lefèbvre P, Luyckx A, LopezHabib G (1973) Glucose naturally labeled with carbon-13: use for metabolic studies in man. Science 181: 445-446

38. Lacroix M, Mosora F (1975) Variations du rapport isotopique ${ }^{13} \mathrm{C} /{ }^{12} \mathrm{C}$ dans le métabolisme animal. In: Isotopes ratios as pollutant source and behaviour indicators. International Atomic Energy Agency, Vienna, pp 343-358

39. Mosora F, Lefèbvre P, Pirnay F, Lacroix M, Luyckx A, Duchesne $J$ (1976) Quantitative evaluation of the oxidation of an exogenous glucose load using naturally labeled ${ }^{13} \mathrm{C}$-glucose. Metabolism 25 : 1575-1582

40. Mosora F, Lacroix M, Luyckx AS, Pallikarakis N, Pirnay F, Krzentowski G, Lefèbvre P(1981) Glucose oxidation in relation to the size of the oral glucose loading dose. Metabolism 30: 1143-1149

41. Krebs HA, Hems R, Weidemann MJ, Speake RN (1966) The fate of isotopic carbon in kidney cortex synthesizing glucose from lactate. Biochem J 101: 242-249

42. Vranic M (1973) Tracer methodology and glucose turnover: an overview. Fed Proc 33: 1837-1840

43. Allsop JR, Wolfe RR, Burke JF (1978) Tracer priming the bicarbonate pool. J Appl Physiol: Respir Environ Exercise Physiol 45: 137-139

44. Krzentowski G, Jandrain B, Pirnay F, Mosora F, Lacroix M, Luyckx A, Lefèbvre P. J (1984) Availability of glucose given orally during exercise. J Appl Physiol: Respir Environ Exercise Physiol 56: $315-320$

45. Costill DL, Benett A, Branam G, Eddy D (1973) Glucose ingestion at rest and during prolonged exercise. J Appl Physiol 34: 764-769
46. Van Handel PJ, Finck WJ, Branam G, Costill DL (1980) Fate of ${ }^{14} \mathrm{C}$-glucose ingested during prolonged exercise. Int $J$ Sports Med 2: $127-131$

47. Pirnay F, Lacroix M, Mosora F, Luyckx A, Lefèbvre P (1977) Glucose oxidation during exercise evaluated with naturally labeled ${ }^{13}$ C-glucose. J Appl Physiol 43: 258-261

48. Pirnay F, Krzentowski G, Crielaard JM, Pallikarakis N, Lacroix M, Mosora F, Luyckx A, Lefèbvre P (1981) Oxidation of orally administered "naturally-labeled ${ }^{13} \mathrm{C}$-glucose" during prolonged muscular exercise. In: Poortmans J, Niset G (eds) Biochemistry of exercise IV B. University Park Press, Baltimore, pp 196-207

49. Pirnay F, Crielaard JM, Pallikarakis N, Lacroix M, Mosora F, Krzentowski G, Luyckx A, Lefèbvre P J (1982) Fate of exogenous glucose during exercise of different intensities in humans. J Appl Physiol: Respir Environ Exercise Physiol 53: 1620-1624

50. Krzentowski G, Pirnay F, Pallikarakis N, Luyckx AS, Lacroix M, Mosora F, Lefèbvre PJ (1981) Glucose utilization during exercise in normal and diabetic subjects. The role of insulin. Diabetes 30: 983-989

51. Apfelbaum E (ed) (1946) Maladie de famine. Recherches cliniques sur la famine exécutées dans le ghetto de Varsovie en 1942. American Joint Distribution Committee, Warsaw

52. Winick M (ed) Hunger disease. Studies by the Jewish Physicians in the Warsaw ghetto. $J$ Wiley and Sons, New York, 1979

53. Björkman O, Berry J (1973) High-efficiency photosynthesis. Sci Am 229: 80-93

54. Lyon TDB, Baxter MS (1978) Stable carbon isotopes in human tissues. Nature 273: $750-751$

Professor P. J. Lefèbvre

Division of Diabetes

Institute of Medecine

University of Liège

$\mathrm{B}-4020$ Liège

Belgium 